\title{
Многоликая бедность
}

Анализ показателей, характеризующих социально-экономическое состояние России за последние годы, свидетельствует о весьма неблагоприятных тенденциях. Наиболее тревожная увеличение уровня бедности, вызванное в первую очередь снижением реальных доходов населения в 2014-2016 гг. (прежде всего, по сравнению с 2013 г.) (см. статью Е.Е. Гришиной). Падение реальных доходов населения ведет к снижению спроса на товары и услуги, что затрудняет официально продекларированный выход экономики страны из состояния рецессии. Но это - «зло еще не так большой руки» по сравнению с тем, что увеличение числа бедных - абсолютное и относительное - ведет к ухудшению здоровья населения и снижению его творческого потенциала.

Очевидно, что активность человека, не имеющего доступа к самым необходимым благам и услугам, направлена не на движение вперед и создание нового, а на самые неотложные нужды. А о том, что не удовлетворяются даже базовые потребности россиян, свидетельствует, например, статистика потребления продуктов питания. Так, Минздрав рекомендует ${ }^{1}$ потреблять не менее 325 кг молочной продукции в год на человека. Но в 2016 г. этот показатель составил лишь 233 кг. С июня 2013 г. по июнь 2017 г. потребление молока упало на 4\%, по мясу - с августа 2016 г. по август 2017 г. падение спроса составило 1,8\%, несмотря на рост внутреннего производства.

Вполне ожидаемо, что в непростых условиях перманентного кризиса россияне все больше усилий и энергии тратят на поиск возможностей хотя бы поддерживать приемлемый уровень жизни (статья С. А. Баркова, О.В. Гавриленко, А. В. Маркеевой, Е.А. Свердликовой). Но это во многом сродни догоняющему развитию - как только ты приблизился к поставленной цели, она оказывается гораздо дальше, чем предполагалось. Такой путь «развития» никогда не позволит выйти в лидеры (разве что при сочетании уникальных внешних условий).

\footnotetext{
${ }^{1}$ Бурлакова Е. Молочные реки не потекли в Россию//Ведомости. 2018. 28 янв. URL: https://www.vedomosti.ru/business/articles/2018/01/22/748479-provalilos-importozamescheniemolochnoi
} 
В дискуссиях по поводу необходимости изменения экономической системы - перехода от централизованного планирования и управления, основанного на предписаниях «сверху», к экономике, базирующейся на преимущественном действии «рыночных сил», в числе важнейших аргументов указывалось на несовместимость плановой распределительной экономики с современной «экономикой благосостояния». А в книге Людвига Эрхарда «Благосостояние для всех» ${ }^{2}$, своего рода культовом манифесте, ознаменовавшем движение в данном направлении, основным лейтмотивом можно назвать обоснование необходимости создания и поддержания «социально-рыночного хозяйства».

Последнее включало не только экономическую систему, обеспечивающую рост благосостояния граждан Германии, но и предоставление им возможностей и условий для развития их потенциала (включая предпринимательский). Сила данной книги, наряду с простотой и ясностью изложения, в представленной в ней исторической правде и в реальной истории успеха (уже через 10 лет с начала преобразований экономика Германии превратилась в «социально-рыночное хозяйство»).

Бедность, рассмотрению разных сторон феномена которой посвящен этот номер, не изжита во всех странах и во всех экономических системах (какими бы «социально ориентированными» они ни были). При этом, безусловно, «пороги бедности» по странам различаются, но государства с социально-рыночным хозяйством, во-первых, предоставляют каждому своему гражданину возможности выйти из этой категории за счет реализации своих возможностей, и, во-вторых, поддерживают гарантированный уровень благосостояния на социально приемлемом уровне.

В первом случае это обеспечивается, прежде всего, путем создания системы связей по линии «общество - государство экономика». Особая роль в формировании социально ориентированной направленности данной связи принадлежит не столько рыночному хозяйству как таковому, сколько тому, что «в рыночном хозяйстве ежедневно и ежечасно осуществляются процессы приспособления, которые приводят к правильному соотношению спрос и предложение, национальную продукцию и национальный

2 Эрхард Л. Благосостояние для всех: Репринт. воспроизведение: Пер. с нем./ Авт. предисл. Б. Б. Багаряцкий, В. Г. Гребенников. М.: Начала-Пресс,1991. 335 с. 
доход...» . Причем этот процесс идет не только на микроуровне уровне отдельных трансакций, он проявляется и в государственной политике, и в применяемых в ней инструментах регулирования. «Законодатель должен считать своей задачей устранение факторов, нарушающих ход рыночных операций» ${ }^{4}$.

Во втором случае необходим учет особенностей различных слоев, категорий и групп населения. На это направлены и статистика, и система предоставления различных форм социальной помощи и поддержки бедным и малоимущим слоям населения.

Нельзя не отметить современную особенность проблемы бедности - растущее в мире неравенство, сосредоточение национального богатства в руках все меньшего по численности населения. Однако ответ на вопрос о том, ведет ли усиление неравенства к росту бедности - как абсолютной, так и относительной, например, на основе оценки бедности по лишениям (депривационной), в целом весьма неоднозначен. В странах и экономиках, где рыночное хозяйство социально ориентированное, порог бедности постоянно повышается, и в сопоставимых измерителях численность бедных имеет тенденцию к уменьшению. Более сложной является оценка динамики депривационной бедности (из-за расширения круга товаров и услуг, обеспечивающих общественно приемлемый минимально допустимый уровень благосостояния).

В любом случае ответы на подобные вопросы в социально ориентированных экономиках неоднозначны, тем не менее, как правило, благосостояние наиболее бедных слоев населения растет, как в абсолютном, так и в относительном (депривационном) ракурсах анализа и оценки.

Ситуация в России, как не раз отмечалось на страницах «ЭКО», в этом плане уникальна: число бедных и малообеспеченных граждан за последние годы имеет тенденцию к абсолютному росту. В числе основных причин этого отметим следующие.

1. Отсутствие многих предпосылок и условий для отмеченного выше «ежечасного» и «ежедневного» приспособления в системе связей «общество - государство - экономика» к меняющимся и весьма специфическим условиям ведения хозяйственной

3 Эрхард Л. Указ. Соч. С. 164.

${ }^{4}$ Там же. С. 166. 
деятельности. Результат - доминирование в экономике не только естественных монополий (производителей тепла и энергии), но и сверхкрупных сетевых структур и холдингов на рынке потребительских товаров и услуг, которые, с одной стороны, обеспечивают их поставку на территории огромной страны по относительно низким ценам по сравнению с региональными рынками, а с другой - ведут к разорению и переходу в разряд «новых бедных» мелких предпринимателей.

2. Негибкость политики социальной поддержки и помощи слоям и группам населения, испытывающим наибольшие затруднения в обеспечении минимально приемлемого уровня благосостояния. В числе причин - не столько отсутствие адаптации экономической и социальной политики к меняющимся условиям, сколько стремление к универсальности применяемых подходов с акцентом на простоту (администрируемость) используемых инструментов.

Вот один из результатов действия таких универсальных подходов: «стартовые условия» благополучия (в виде бесплатно приватизированного жилья в 1990-е годы) постепенно сходят на нет, и на подходе «новые бедные» (статья Т. Ю. Черкашиной).

Настоящий номер журнала является попыткой восполнить пробелы в данной области и способствовать формированию адекватных подходов с целью учета особенностей бедности различных слоев и групп населения. А именно, семей с детьми (прежде всего неполных и многодетных) (статья Е.Е. Гришиной), людей пожилого возраста (статья П. Кузнецовой), инвалидов (статья Р.Р. Хасановой и А.О. Макаренцевой).

В социальной политике нет мелочей и второстепенных сюжетов. В то же время нет и не может быть догматического и универсального подхода. И если не следовать этим простым истинам и не учитывать многоликость бедности, создание «социально-рыночного хозяйства» в нашей стране может еще надолго задержаться на стадии «идей» и «замыслов».

Главный редактор «ЭКО»

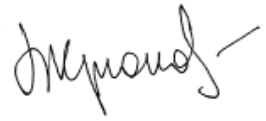

КРЮКОВ B.A. 